\title{
Problems of Reforming of Housing and Communal Services of Cities of Irkutsk Region in the 1990s
}

\author{
Tatiana P. Urozhaeva* \\ Irkutsk State University \\ 1 Karl Marks Str., Irkutsk, 664003, Russia
}

Received 24.10.2015, received in revised form 14.01.2016, accepted 24.03.2016

The aim of the article is the analysis of main trends and implications reforms in housing and communal services of cities of Irkutsk region in the first post-Soviet decade. The subject of research is the reform of housing and communal services, which provided a radical change from the planning and administrative methods of regulation of the housing sector to market mechanisms. The study tested hypothesized that the attempts of state authorities to entrust the accumulated problems in the industry on municipalities in isolation from the reform of public utilities, domestic service etc., and, most importantly, empowerment of local government in the pricing and quality of public services, and are unable to lead to the desired results. In the course of writing were used research methods of social phenomena in historical perspective, analyzes a variety of information sources and literature. The benefits of this study in studied publications in local, regional and central periodicals, monographs and articles, as well as statistical materials. The article concludes that the formation of the mechanisms of the sphere housing and communal services occurred in the conditions of hard budget constraints, there was a constant search of balance in the cost of housing between the population and the budget. Consequently, not enough has been worked out, and the conditions of the contractual relationship. The city authorities in some cases had no effect on the prices for heat generation and water, their transport and distribution. Ultimately, these and other problems indicated a significant difficulties in the process of reforming of housing and communal services.

Keywords: municipal ownership, housing and utilities, budget deficit, tariffs, emergency.

DOI: 10.17516/1997-1370-2016-9-4-932-939.

Research area: sociology, culture studies.

Housing conditions of the population include several indicators that affect the quality of life in the city. These include: the state housing stock and its increase; existing utilities; landscaping and maintaining the cleanliness of the city's yard territories. For many years the sphere of housing and communal economy of cities were formed as a complex, diversified system in terms of centralized management, covering over 30 different activities (housing, heat, electricity, gas, water, sewage, landscaping, hotel and bathlaundry services and other).

The Soviet experience of operation of housing under state ownership was based on the

\footnotetext{
(C) Siberian Federal University. All rights reserved

* Corresponding author E-mail address: olgoy@yandex.ru
} 
endowment principle of financing the utilities. The state of the housing stock was unprofitable, as received from tenants rents was "the lowest in the world" and covers not more than $5 \%$ of the costs. In fact, it was funded from the budgets of ministries, agencies, enterprises or organizations under whose authority were the objects of housing and communal services, and in the end a heavy strain on the state budget.

The first post-soviet decade, by definition, can be described as the period of "municipal revolution." It was then greatly expanded the powers of local (city) government. He has acquired many socially important functions, including the maintenance of public facilities. However, reform of housing and communal economy, which began in 1992, came from view it not as life support but as a kind of business activity, which should be cost-effective and regulated market relations. The idea of reform was to hold the "denationalization" of public utilities, to deprive it of its "municipal" character, remove from the state the responsibility for maintenance of housing and utilities (The concept of reform, 1997). Thereby changing the principles of financed, gradually decreased the share of budget expenditures for the maintenance of the system (they are increasingly shifted to the population). As a results, rapidly increased the prices and tariffs. At the same time significantly decreased, compared with other industries, wages of workers of municipal services, which led to a decrease in the quality of personnel potential. The unbundling and partial privatization of the sector has caused the deterioration of its material and technical base.

By the early 1990s, the deterioration of an engineering infrastructure of housing and utilities reached in the region of $70-80 \%$, which resulted in an increase of emergency situations and accidents. According to the data of State building of the RSFSR, $100 \mathrm{~km}$ of water networks accounted for 73 damage, and the amount of annual replacement of the pipes was three times less than the minimum allowable limit. Due to the inefficient system of management continued ageing of the housing stock, reducing the reliability of engineering systems, growth of debts to energy, gas, heat supply enterprises. Particularly acute this problem was in the far North, where more severe climatic conditions, and, accordingly, management and the development of municipal services become particularly relevant.

Required reconstruction of the boiler equipment and heating utilites, water and sewer networks. The number of emergency situations in the sphere of housing and communal services of the Irkutsk region has increased dramatically. At the time, everyone's lips were so problematic (from the point of view of the state of housing and communal services) of the city of Irkutsk region: Ust-Kut, Tulun, Svirsk and other.

Gradually increased the share of payments for housing and communal services: from $9 \%$ in 1993 to $56 \%$ in 2000. In the Irkutsk region from 1994 to 1997, prices for housing and communal services grew. In particular, rents in the public housing stock grew by nearly 16 times, electricity - 10 times, for water supply and Sewerage - by 19 times, the heat -47 , the hot water supply 68 at times, for gas - in 16 times (Housing and communal services of the Irkutsk region, 1995, 1998).

Despite the constant increase of prices for housing and communal services, the industry remained a large number of problems. The main problems in the 1990s were: the deterioration of municipal infrastructure (upgrading required); the subsided sector; the reluctance of citizens who are homeowners, are actively involved in the process of housing management and other. In the period from 1992 to 1999, the municipalities were gradually transferred to the utilities and most of the housing stock. In the end, more than $90 \%$ 
of the budgets of the cities of the Irkutsk region were unprofitable, the most burdened social infrastructure. They have virtually disappeared from the reserves for development. In fact, the Federal center and the region took a lot of resources, but the responsibility shifted to local governments. In the 1999 budgets of the cities of Irkutsk region accounted for $32 \%$ of spending at $17 \%$ of income (Housing and communal services of the Irkutsk region, 2000). The housing sector was in a state of severe systemic crisis, becoming a brake on economic growth and a source of high social tension in the region.

Housing and communal services financed from all sources of not more than $50 \%$ of the needs, which allowed them to provide only the reproduction of fixed assets. The lack of funding had the following negative consequences: decreased level of urban redevelopment; significantly deteriorated municipal services to the population; more than 20 times (in the period from 1992 to 1994) increased rents and the cost of services. For example, in August 1992, compared with the corresponding month in 1991, there was a significant growth of prices for housing and communal services. They increased in 8.2 times (Sokolov, 1992). Five years of experience in the implementation of the reform showed that the way to achieve utility costs at the expense of increase of tariffs has been exhausted. Public expenditures for housing and communal services (in per person per month) has increased in the region from 1991 to 19965.5 thousand times. Meanwhile, as a share of budgetary subsidies to cover losses fell from $99 \%$ of the service cost in 1992 to $60 \%$ in 1997 (Ivanova, Kendenkov, 1998). In 1997 , more than $40 \%$ of the inhabitants of the cities of the Irkutsk region were unable to pay utility bills. With increasing rates of nonpayments only increased. The fee for the gas networks of the person has increased in 1.7 times. As a result, the index for paid services provided to the population amounted to $110.5 \%$ (Konkin, 1998).

After the August 1998 crisis, tariffs for housing and utility services went up in accordance with the schedule adopted by the program of reforming of housing and communal services. Urban residents of the Angara region have already paid $50 \%$ of all expenditures on housing and utilities. Rates for utilities continued to rise, so as to reimburse the costs of heat production, except there was no one consumer is the main consumer (industry) were in severe crisis (Shchepina, 1999).

Despite the growth of municipal tariffs, the workers were not always able to get the earned money in time. Driven to despair by chronic delay of wages, debts which of May 1997 was \$184 billion non-denominated rubles, housing and communal services were compelled to resort to extreme measures of protest. For example, employees of housing and communal services, Sayansk was periodically shut off the cold water in some organizations of the city (Sense of dutythat we have no money, 1998). Due to the unstable work of the main enterprise "Sayanskhimprom", the timing of payment of wages to housing and communal services remained uncertain.

Despite promises by leaders of local authorities on repayment of debts, their size in the Angara region did not fall below $\$ 150$ billion non-denominated rubles. Especially the critical situation has developed in the cities Bratsk and Ust-Ilimsk, where debt has reached eight months. It was planned that if after achieved with the administration of the agreements will not be honored schedules of repayment of debts on a salary, companies of housing and communal enterprises will begin an indefinite strike (Kuklina, 1997).

At the beginning of December 1999 the total amount of overdue wage arrears in housing area exceeded 258 million denominated rubles. 
While payables of the Federal bodies for the consumption of utilities has reached 314 million rubles a particularly difficult situation, in Bodaibo and Ust-Kut. Here salary is not seen for 10-15 months, and repaid it with food, industrial goods above the market price in half to two times (Shekalov, 1999).

In 1998 half worked empty the water system and Baikalsk, Bratsk (losses 46-47\%), Usolye-Siberian - 29\%. Unfortunately, not all settlements had wastewater treatment plants, and where they existed, were often insufficient bandwidth. In Ust-Ilimsk and Bodaibo without cleaning in river Angara and Lena got about 60 $70 \%$ of wastewater. Still one of the sore points of public utilities was the heating boiler. From over 800 boilers $70 \%$ were small, low-power and therefore ineffective, providing only $12 \%$ of the total generated thermal energy. More than a third of heating systems needed to be replaced. Every year they lost $17-18 \%$ heat delivery (Shchepina, 1999).

To the dismay of the population, housing services rose in price quite substantially. Only in 1998 they increased by $20.5 \%$. The cost of services the population were dependent on local budgets to support this sector of the economy. This explains the repeated difference in the level of tariffs in the towns of the region. In 1999, most were different tariffs for water and sanitation: from 82 kopecks per month for residents of Zheleznogorsk-Ilimskiy to 1.8 rubles in UstIlimsk (Housing and communal services of the Irkutsk region, 2000).

In January 1999, the cost of utilities amounted to 7.9 rubles per square meter of the total area. This was below the Federal standard of cost of 2.9 rubles. However, these frameworks proved to be too narrow for housing and communal services, Bodaibo and UsolyeSiberian. The urban population paid on average only a third of these costs. The main reason of non-payment - lack of funds generated by low salaries and pensions, their delays and rising prices. In 1999, debts of inhabitants of Ust-Kut, Sayansk and amounted to more than half of which are due for payment amounts. In UsolyeSiberian, Zheleznogorsk-Ilimskiy and Baykalsk was not brought in time from 30 to $44 \%$ of payments (Shchepina, 1999).

Population's expenditures on housing and other creature comforts were limited to one indicator. In different cities of the region, they should not exceed $15-18 \%$ of total family income. If you exceed this limit, the family is entitled to the subsidy, namely, the reduction of payments. Most actively worked with service subsides in Bodaibo, where $17-19 \%$ of families actually exercise this right. In 1998, they've managed to use 23 thousand families of citizens. Each of them was fairly modest amount - to 29 rubles. A month and a total for the year this resulted in 8 million rubles have documented entitlement to benefits 432 thousand inhabitants of area. Of these, 7\% are unable to implement it. The reason for partial funding of these costs: when 168 million rubles were spent 128 million rubles (Ovsyannikova, 1999).

In 1999, the budgets of all levels to organizations housing grants were provided in the amount of housing and communal services 546.5 million rubles, including from the main budget of the country, the federal - less than $1 \%$. On and Sayansk, Usolye-Siberian subsidies from the budget were not allocated. Heavy "weight" to this load were debts of the population on payment of housing and household amenities. Not paid on time $15 \%$ of the assessed amounts. In some cities of the region this debt was much higher: in Saiansk and Bodaibo - 17\%, in Shelekhov, UstKut and Angarsk - 18-20\%. The highest debt remained in Zheleznogorsk-Ilimskiy (29-30\%), minor - in Bratsk, Ust-Ilimsk and Baykalsk (3-7\%) (Ovsyannikova, 1999). 
Overall, utilities the urban area was in heavy crisis. The housing stock continued to deteriorate, however, the area of repaired houses gradually decreased. For example, in 1996 it amounted to not much more than 180 thousand $\mathrm{m}^{2}$ thousand $\mathrm{m}^{2} .530$ in 1990, public Expenditures for housing and communal services per person by region in the period from 1991 to 1996 grew by 30 times. The share of budgetary subsidies to cover losses decreased from $99 \%$ (of the cost of services) in 1992 up to $60 \%$ in 1997. As a result, in Bratsk, Angarsk, Usolye-Siberian the share of overdue debt of the population for rents amounted to $35 \%$. More than a third of the population was unable to pay for their homes at rates, which account for almost $25 \%$ of their actual cost. The maximum permissible share of own expenses on payment of municipal services should not exceed $16 \%$ of total income. In the future, this standard was increased in the following amounts: $1998-18 \%$; $1999-19$; 2000 - 20 (Antonenko, 2000).

Maintenance and servicing of housing cost at the end of 1999 housing and communal services on the average on $6-8$ rubles per $m 2$ of total area. It was almost twice lower than the government standard for regions of Eastern Siberia. Savings wore a forced nature and lack of the necessary funds. The burden fell mainly on local budgets. Ten months of 1999 from the budgets of all levels of organizations of housing and utilities were allocated subsidies in the amount of housing and communal services 546.5 million rubles, including from the main budget, Federal, $1 \%$ of the market.

The size of the budget subsidies has remained volatile and within 1999 ranged from 1 to 3 rubles per square meter. In the Sayansk and Ust-Kut subsidies from the budget were not allocated. Part of the expenses was unable to offset the budget, turned to losses of housing and communal enterprises. Heavy appendage to this load were debts of the population on payment of housing and household amenities. Not paid on time $11 \%$ of the assessed amounts. In some cities of the region this debt was much higher: the Sayansk and Bodaibo - 14\%, in Shelekhov, Ust-Kut $-16-20 \%$. The highest debt remained in Zheleznogorsk (30\%), minor $\square$ in Ust-Ilimsk $(7 \%)$. By early 2000 , the regional average tenants pay less than 3 rubles per unit area that was not the half of the housing and utility costs. Under the reform work on social protection has been slow. In 1999, the share of families receiving housing subsidies had increased from 2 to $3 \%$. In Ust-Kut, Zheleznogorsk and Svirsk such families was less than $1 \%$. The size of the subsidies was small $\square$ on average seven to 15 rubles a month. It was possible to extinguish only one fifth of total assessed subsidies. In addition, 643 thousand inhabitants of the Irkutsk region have enjoyed the benefits on payment of housing and communal services (Ovsyannikova, 1999).

In 1999, the maximum amount of payments for housing and communal services was approved at $50 \%$ of their value. However, in every third town in the region, based on the capabilities of local budgets, was set lower limit (from 20 to $45 \%$ ). Pay less on legitimate basis could the inhabitants of the Ust-Ilim, Ust-Kut, Shelekhov and Zheleznogorsk-Ilimskiy. In addition, housing and utility payments of the population could be reduced if there is insufficient household income. If the family, with its living area in the framework of the approved social norms, was forced to spend on housing and other "amenities" greater than envisaged, the share of its modest budget, she is entitled to a housing subsidy. Really enjoy this right while only $2.5 \%$ of families living in the Angara region. The size of grants was small $\square 11$ rubles per family per month. However, in General for this purpose on a monthly basis compared to about 700 thousand rubles. More active than in other cities, the work on allocation of housing subsidies was held in the town of Bodaibo 
and Shelehov, where the endowment payout used from 7 to $28 \%$ of residents (Subsidies for "convenience", 2000).

In the spring of 1999, has remained unprofitable for $76 \%$ of utilities (in the economy of Angara 65\%). The sum of their losses in 1998 (474 million) "more than cover" a small profit 53 million. Of all housing and communal services remained profitable only electricity, all other services of the tenants of a loss. Budget replenishment in 1998 offset the losses from maintenance of housing, and in other areas of service ranged from 18 to $68 \%$ of the amount of losses.

In General, the characteristic feature of the municipal utilities of the cities of the Irkutsk region in the reform period (19922000) was the relatively low level of industry development, reflected in outdated techniques and technologies, backward methods of production organization, high wear and tear of buildings, the use of outdated materials. A significant proportion of the housing stocks (80\%) were houses from precast concrete, which by design data the most wasteful buildings. On water and sewer networks occurred regularly breakthroughs, disable and crash that caused not only the loss of water and irregular water supply, but environmental pollution, violation of sanitary well-being of cities (Lunaca, 2000).

Housing reforms have provided a radical change from the planning and administrative methods of regulation of the housing sector to market mechanisms. However, the attempts of state authorities to entrust the accumulated problems in the industry on municipalities in isolation from the reform of key economic sectors (energy and utilities, domestic service and other), and, most importantly, empowerment of local government in the pricing and quality of public services, and are unable to lead to the desired results.
The governance structure of housing and communal services of cities of the Irkutsk region was not initially configured to control and reduce costs, had no experience in conditions of severe budget constraints. There was no competition in the provision of utility services. Where not designed tender procedures on maintenance of the housing stock and major repairs. The ability of the control system housing to provide lower costs of capital repairs at the expense of checking their validity, standardization and quality control of work, changing modes of selection of contractors for execution of works depended the financial stability of the housing of the urban settlements. Residential buildings have not been provided with meters and regulation of heat consumption and water. In the cities of Irkutsk region was observed «overheating» buildings and lost a significant amount of heat.

The trunk lines were in poor condition, and requires repair. The city authorities at times often lacked the opportunity to influence the tariff setting for heat supply. When allocating tariff for the transport of thermal energy the cost of repair of distribution networks had to be elicited from the structure of housing services and included in the costs for transport of thermal energy. In the cities was not the program of measures to improve energy efficiency in buildings and engineering infrastructure.

In General, formation of mechanisms of work of housing and communal services has occurred in the face of constant budget constraints, there has been a reduction in the costs of contents housing and communal services. There was a constant search of balance in the cost of housing between the population and the city budget. The boundaries of responsibility wore a fuzzy nature and have not been set in the contracts; not enough has been worked out, and the conditions of the contractual relationship; the cities had no impact 
on the prices for heat generation and water, significant difficulties in the process of reforming their transport and distribution (Abolin, 2000). of housing and communal services in the cities of All these and other problems have highlighted Irkutsk region.

\section{References}

Abolin, A. (2000) The main directions of reforming housing and communal services of municipalities. Housing and communal services, 2 (1), 27.

Antonenko, A. (2000) How to plug a black hole. SM-number one. December 27, 2-3.Housing and communal services of the Irkutsk region. Statistic 1994 collection (1995). Goskomstat of the Russian Federation, Irkutsk Oblkomstat, 11; Housing and communal services of the Irkutsk region: Statistic 1997 collection. Goskomstat of the Russian Federation, Irkutsk Oblkomstat, 18.

Housing and communal services of the Irkutsk region: Statistic 1999 collection (2000). Goskomstat of the Russian Federation, Irkutsk Oblkomstat, 37, 51.

Ivanova, I., Kendenkov, K. (1998) Reform of housing and communal services in the Irkutsk region: includes data on the financial situation of housing and communal enterprises, the volume of services, tariffs on services in the cities of Irkutsk region, In Questions of statistics. 11, 55-56.

Konkin, M. (1998) Do we have a future?, In Russian newspaper, March 14. (ADJ.: Baikal-Lena), 11 .

Kuklina, N. (1997) Is there indefinite?, In SM-number one. November 20, 2.

Lunaca, O. (2000) Keepers of cities: towards the 350th anniversary of work of housing and communal services of the Irkutsk region, In Arguments and facts, June, (26), 16.

Ovsyannikova, I. (1999) The Reform of the housing: the steeplechase, In East-Siberian truth, March 20, 2.

Ovsyannikova, I. (1999) The Heavy burden of living comfort, In East-Siberian truth, December 2, 2-3.

Sokolov, V. (1992) Purse and statistics, In East-Siberian truth, 145, August 14, 2.

Subsidies, for "convenience" (2000), In SM-number one, January 27, 3.

Sense of duty-that we have no money (1998), In Sayan dawns, May 31, 1.

Shekalov, V. (1999) Below the sewer level. SM-number one, December 23, 2.

Shchepina, V. (1999) Monitoring of the reform of housing and communal services in cities and districts of Irkutsk region (1998), In Bulletin of Irkutsk state economic Academy, Irkutsk, 4 (21), 66-67, $72-73$.

The concept of reform of housing and communal services in Russia (1997), In Construction paper, $22,11$. 


\title{
Проблемы реформирования
}

\section{сферы жилищно-коммунального хозяйства \\ городов Иркутской области в 1990-е гг.}

\author{
Т.П. Урожаева
}

Иркутский государственный университет Россия, 664003, Иркутск, ул. Карла Маркса, 1

\begin{abstract}
Целью статьи является анализ основных направлений и последствий реформы сферы жилищно-коммунального хозяйства городов Приангарья в первое постсоветское десятилетие. Предметом исследования является реформа ЖКХ, которая обеспечила коренной переворот от планово-административных методов регулирования жилищной сферы к рыночным механизмам. Автором была выдвинута гипотеза о том, что попытки государственных органов власти возложить накопившиеся проблемы в отрасли на муниципалитеты в отрыве от реформирования коммунальной энергетики, бытового сервиса и т.д., а главное - расширение полномочий местного самоуправления в иенообразовании и контроле качества коммунальных услуг так и не смогли привести $\kappa$ желаемым результатам. В ходе написания статьи были использованы методы исследования соииальных явлений в исторической ретроспективе, проанализировань разнообразные информационные источники и литература. Автором были исследованы публикации в местных, региональных и иентральных периодических изданиях, отдельнье монографии и статьи, а также статистические материалы. В статье был сделан вывод о том, что формирование механизмов работы сферы жилкомхоза происходило в условиях жестких бюджетных ограничений, шел постоянный поиск баланса в покрытии расходов на ЖКХ между населением и бюджетом. Следовательно, недостаточно была проработана система и условия договорных отнотений. У городских властей в ряде случаев не оставалось рычагов влияния на цены тепла и воды, транспорт и распределение. В итоге эти и другие проблемы свидетельствовали о значительных трудностях прочесса реформирования сферы жилищно-коммунального хозяйства.
\end{abstract}

Ключевые слова: муниципальная собственность, жилищно-коммунальное хозяйство, бюджетный дефиџит, тарифы, аварийные ситуации.

Научная специальность: 22.00.00 - сочиологические науки, 24.00.00 - культурология. 